\title{
Path Analysis and Health Belief Model on the Association between Education and Cadre Performance in Tuberculosis Control at Baki Community Health Center, Sukoharjo, Indonesia
}

\author{
Dhian Nurayni Sulistyo Ningrum(1), Bhisma Murti'), Ruben Dharmawan²) \\ ${ }^{1)}$ Faculty of Public Health, Universitas Sebelas Maret \\ 2)Faculty of Medicine, Universitas Sebelas Maret
}

\begin{abstract}
Background: The new cases of tuberculosis in 2014 as many as 9.6 million. There are 6 million cases reported findings. The efforts to increase the number of case finding through co-operating community and community health workers. This study aimed to analyze the association of education and health belief model with a performance of cadres in tuberculosis control.

Subjects and Method: This was an observational analytic with a cross sectional design. This was conducted in community health center of Baki, Sukoharjo, Indonesia, in April 2016. A sample was 90 subjects were selected by random sampling. The data collection used questionnaire. The data were analyzed using path analysis.

Results: There was no relationship between education and the performance of cadres in tuberculosis control cases through the perception of vulnerability, perceived seriousness, perceived benefit, perceived barriers and self-efficacy. There was a direct positive relationship between the perception of vulnerability to the performance of cadres in tuberculosis control cases $(b=3.35 ; 95 \% \mathrm{CI}=1.43$ to $5.27 ; \mathrm{p}=0.001)$, seriousness $(\mathrm{b}=2.21 ; 95 \% \mathrm{CI}=0.43$ to $3.9 ; \mathrm{p}=0.015)$, benefits $(\mathrm{b}=2.11 ; 95 \% \mathrm{CI}=$ 0.42 to $3.80 ; p=0.014)$, self-efficacy $(b=2.04 ; 95 \% \mathrm{CI}=-0.01$ to $4.09 ; \mathrm{p}=0.051)$, the impulse to act $(b=1.64 ; 95 \% \mathrm{CI}=0.06$ to $3.22 ; \mathrm{p}=0.042)$ with the performance of cadres in the control of tuberculosis cases. There was a direct negative relationship between perceptions of barriers to the performance of cadres in tuberculosis control $(b=-4.54 ; 95 \% \mathrm{CI}=-7.56$ to -1.52$) ; \mathrm{p}=0.003)$.

Conclusion: There is an indirect relationship between education and performance of cadres in tuberculosis control cases through the perception of vulnerability, seriousness, benefits, barrier, and self-efficacy. There is a direct relationship between the construct of health belief model with the performance of cadres in tuberculosis control cases.
\end{abstract}

Keywords: path analysis, education, health belief model, the performance of cadres, tuberculosis

\section{Correspondences :}

Dhian Nurayni. Sulistyo Ningrum. Masters Program in Public Health, Universitas Sebelas Maret. Jl. Ir. Sutami 36A, Surakarta 57126, Central Java. Email: dhiannuraynis@gmail.com

BACKGROUND
Tuberculosis (TB) is one of the main prob-
lems that occur in global health. TB is the
second leading cause of death in the world
after HIV. Mortality with TB in 2014 reach-
es $1,500,000$ inhabitants and of which
140,000 are older children. WHO in 2014
estimates as much as 9,600,000 new TB
cases with 5,400,000 are men and women
are $3,200,000$ and children are $1,000,000$.
Based on these estimates about $6,000,000$
TB cases are reported. When compared to the estimated figure 9.6 million new TB cases, reports of such cases only amounted to $63 \%$. Thus in the world there are $37 \%$ of new TB cases are undiagnosed or not reported. Indonesia is the second country from the five countries with the largest number of incidence of TB cases in the year 2014, namely India (2.0 to 2.3 million), Indonesia (0.7 to 1.4), China (0.8 to 1.0), Nigeria (0.34 to 0.87 ) and Pakistan (o.37 to 0.65). The estimated incidence of TB in Indonesia is 1 million per year (WHO, 2000). 
Tuberculosis is an infectious disease caused by the bacteria Mycobacterium tuberculosis can invade a variety of organs and tissues of other organs, but more often is stricken with lung (Steingart et al., 2001; Kemenkes, 2015). TB has a characteristic way of easy transmission over the air, namely sprinkling droplets or phlegm. Control of TB transmission is done by the strategy of Directly Observed Treatment Shortcourse (DOTS) in accordance with the recommendations of the World Health Organization (WHO) in 1994. This strategy consists of top five pillars, namely: 1) Commitment of political decision makers, 2) Diagnosis and examination of microscopic sputum sufferers, 3) Guarantees the availability of the drug and its distribution lines, 4) direct Supervisors taking medication (PMO) and 5) using a recording of reporting in facilitating monitoring and coaching (Kemkes, 2013; Maryun, 2007). The discovery of TB sufferers suspects on a strategy of DOTS using passive case finding, namely that networking is only done on sufferers who came for a visit at the health service center which in this case is the health centers. Networking in this way cannot crawl suspect TB that is not visited on the health service center, so some sources of transmission cannot be prevented early (Wahyudi, 2010).

The World Health Assembly (WHA) declared the achievement of success strategies DOTS in the detection of new cases of SMEAR-positive $70 \%$, and the healing of $85 \%$ of the cases in 2000 (WHO, 2009).

Another strategy introduced the WHO in 2006 was the stop TB partnership which aims to intensify the response to $\mathrm{TB}$ and reach out to all patients. The stop TB partnership strategy has six components, namely: 1) expansion and enhancement of highquality DOTS, 2) addressing TB/HIV, MDR-TB and other challenges, 3) health systems strengthening, 4) involvement of all health caregivers, 5) empowerment of patients and communities, 6) encourage and enhance research (WHO, 2006). The second strategy that runs either DOTS or stops TB partnership cannot realize the targets of the MDGs in lowering the prevalence and mortality with TB quickly up to half by 2015 (Dyeet et al., cit Murti, 2005).

The indicator is seen in the success of TB control include product Case Detection Rate (CDR), Case Notification Rate (CNR), the proportion of children TB patients, the number of TB treatment success and patient TB treatment proportion RR/MDR TB. CDR indicator is used to describe the scope of the invention of new TB patients with SMEAR positive. The tendency or the trend of CDR that happened in Indonesia has decreased from $60 \%$ in 2013 be $46 \%$ in 2014. The decline also occurred in the CDR product Sukoharjo Regency i.e. from 33\% in 2013 to $30 \%$ in 2014. The case at one of the clinics in the region namely Sukoharjo Regency Health Center Tray, close to CDR 2014 decreased compared to 2013 from $25.6 \%$ to $23.78 \%$. This means that at the national level as well as in areas close to the CDR is still far from the target of 70\% that is declared by the WHO (Kemkes, 2015; DKK Sukoharjo, 2014).

Research conducted Murti et al., (2015) in Sukoharjo note that CDR product failure factors, among others: 1 CDR's discovery) rely more on passive case finding (PCF) and have yet to optimize active case finding (ACF), 2) has not been optimal participation of communities and social capital, 3) networking suspect TB sufferers are too loose (too sensitive) because many suspects who netted although it doesn't meet the criteria, 4) quality of phlegm. Similar to the research by Awusi et al., (2009) that identifies that networking suspect, service IEC (Information, Education, 
Journal of Health Policy and Management (2016), 1(1): 38-43

https://doi.org/10.26911/thejhpm.2016.01.01.06

Communication) and training DOTS officer influential positive clinics at the discovery of TB cases and can increase CDR. The low discovery TB cases that occur will result in increasing morbidity, disability, mortality, and transmission.

SUBJECTS AND METHOD
This was an analytic observational study
with cross sectional design. This was con-
ducted in community health center of Baki,
Sukoharjo, Indonesia in April 2016. A total
sample of 90 subjects was selected by ran-
dom sampling. The independent variables
were education, perception, perception of
the seriousness of the vulnerability, the per-
ception of the benefits, barriers, self-
efficacy perception and encouragement Act.

The dependent variable was the performance of cadres in controlling TB cases. The data analysis was used Path Analysis.

\section{RESULTS}

The characteristics of the subjects in the study were age and employment status. The category of age (50 years $<67.8 \%$ ) and age $\geq 50$ years $(32.2 \%)$. Subject categories that do not work $(55.6 \%)$ and subject to the status of work (44.4\%).The relationship in multivariate describes the relationship of more than one independent variable on education, vulnerability perception, perception of the seriousness of the benefit, barriers, self-efficacy perception and encouragement Act. The method used is the path analysis using STATA program 13.

Table 1. Result of path analysis associated education and invalid construct belief model with the performance of cadres in controlling tuberculosis cases

\begin{tabular}{|c|c|c|c|c|c|c|}
\hline \multirow{2}{*}{$\begin{array}{l}\text { Independent } \\
\text { Variable }\end{array}$} & & \multirow{2}{*}{$\begin{array}{l}\text { Dependent } \\
\text { variable }\end{array}$} & \multirow[b]{2}{*}{$\mathbf{b}$} & \multicolumn{2}{|c|}{$95 \% \mathrm{CI}$} & \multirow[b]{2}{*}{$\mathbf{p}$} \\
\hline & & & & $\begin{array}{l}\text { Lower } \\
\text { limit }\end{array}$ & $\begin{array}{c}\text { Upper } \\
\text { limit }\end{array}$ & \\
\hline \multicolumn{7}{|l|}{ Direct Effect } \\
\hline Performance & $\leftarrow$ & Vulnerability & 3.35 & 1.43 & 5.27 & 0.001 \\
\hline Performance & $\leftarrow$ & Seriousness & 2.21 & 0.43 & 3.99 & 0.015 \\
\hline Performance & $\leftarrow$ & Benefit & 2.11 & 0.42 & 3.80 & 0.014 \\
\hline Performance & $\leftarrow$ & Barriers & -4.54 & -7.56 & -1.52 & 0.003 \\
\hline Performance & $\leftarrow$ & Self-efficacy & 2.04 & -0.01 & 4.09 & 0.051 \\
\hline \multirow{2}{*}{\multicolumn{7}{|c|}{ Indirect effect }} \\
\hline & & & & & & \\
\hline Vulnerability & $\leftarrow$ & Education & 1.32 & 0.33 & 2.30 & 0.009 \\
\hline Seriousness & $\leftarrow$ & Education & 1.08 & 0.08 & 2.07 & 0.033 \\
\hline Benefit & $\leftarrow$ & Education & 0.78 & -0.11 & 1.69 & 0.089 \\
\hline Barriers & $\leftarrow$ & Education & -1.23 & -2.15 & -0.32 & 0.008 \\
\hline Self-efficacy & $\leftarrow$ & Education & 0.45 & -0.46 & 1.37 & 0.329 \\
\hline \multicolumn{7}{|c|}{ Likelihood Ratio= -296.54 } \\
\hline
\end{tabular}

\section{DISCUSSION}

There is an indirect relationship between education and the performance of cadres on controlling tuberculosis cases between education and the perception of vulnerability $(b=1.32$; CI $95 \%=0.33$ to $30 ; p=355)$, continued from the perception of vulnerability to the performance of cadres on controlling tuberculosis (case $\mathrm{b}=3.4 ; 95 \% \mathrm{CI}=$ 1.43 to $5.27 ; \mathrm{p}=0.001)$. Then between edu- cation and perceptions of seriousness $(b=$ 1.08; CI95\%=0.08 to $2.07 ; \mathrm{p}=0.033$ ), continued from the perception of seriousness to the performance of cadres on controlling tuberculosis (case $\mathrm{b}=2.21$; CI $95 \%=0.43$ to 3.9; $\mathrm{p}=0.015)$.

The relationship between education with the perception of benefits $(b=0.78$; 95\% $\mathrm{CI}=-0.11$ to $1.69 ; \mathrm{p}=0.089$ ), continued from the perception of benefit to the perfor- 
mance of cadres on controlling tuberculosis (case $\mathrm{b}=2.11 ; 95 \% \mathrm{CI}=0.42$ to $3.80 ; \mathrm{p}=$ 0.014). Then between education and perceptions of barriers $(b=-1.23 ; 95 \% \mathrm{CI}=-2.15$ to $-0.32 ; \mathrm{p}=0.008$ ), continued from the perception of obstacles to the performance of cadres on controlling tuberculosis cases $(\mathrm{b}=-4.54 ; 95 \% \mathrm{CI}=-7.56$ to $-1.52 ; \mathrm{p}=$ 0.003). The relationship between education and self-efficacy $(b=0.45 ; 95 \% \mathrm{CI}=-0.46-$ 1.37; $\mathrm{p}=0.329$ ), proceed from self-efficacy to the performance of cadres on controlling tuberculosis (case $\mathrm{b}=2.04 ; 95 \% \mathrm{CI}=-0.01$ to 4.09; $\mathrm{p}=0.051)$.

Education affects the way a person's point of view against themselves and the environment, as well as human, leads to action. Education cadres affect control of tuberculosis cases primarily in the process of granting material in extension and capability discovery suspect tuberculosis. This research fits with research (Trisnawati, 2008) that education plays a major role in productivity, if the higher education then the level of productivity in doing a better job. In line with this, the results of similar studies also suggested that high levels of education produce good performance (Khayati, 2012). The performance of cadres is the work of cadres in performing a health behavior, in this case, is the control of tuberculosis cases of the disease.

Education is the process of learning both formal or informal that complement each other to enrich their knowledge. Social cognitive theory by Bandura (1986) that most of the knowledge and behavior drove from the neighborhood and thought processes to information received. The derivative of this theory includes self-efficacy. Selfefficacy is expressed as one's belief that he can run the task on a certain level that affects private activities toward the achievement of the tasks (Bandura, 1986).
Research results showed that the relationship between education and self-efficacy is positive 0.45 which means that a subject with a high education has a smaller average 0.45 to have a good self-efficacy. The results of this study are in line with the results of Biological Research (2010) stating that a person can accomplish tasks that are outside of its ability just solely with the belief that he is capable of (self-efficacy) but rather in need of harmony between the confidence on the one hand and its own merits as well as the knowledge he had gained from the learning process.

Based on the Health Belief Model (Taylor, 2003; Glanz, 2002) health behaviors indirectly influenced by individual characteristics include demographic, psychosocial variables and structural. Sosiodemografic factors in detail especially education is believed to have indirect effects on health behaviors are influenced by the perception or the understanding of vulnerability, seriousness, benefits and barriers in the Health Act or behaviour in order to prevent and treat a disease (Dwijayanti, 2011).

There is a direct relationship between positive perception of vulnerability and the performance of cadres on controlling tuberculosis cases. The value of the coefficient on line on this relationship mean cadres with the perception of vulnerability to experiencing a high tuberculosis disease have score logic performance cadres on controlling tuberculosis cases 3.4 units higher than the perception of low vulnerability $(b=3.4 ; 95 \%$ $\mathrm{CI}=1.43$ to $5.27 ; \mathrm{p}=0.001$ ).

The performance was heavy influenced by various factors such as variable factor is psychological variables consists of sub-variables namely perception, attitude, and personality (Maryun, 2007).

The results of this study in accordance with the theory of the Health Belief Model 
(Rosenstock, 1982), which states that a person has the perception of vulnerability (perceived susceptibility) of individuals affected any possibility of a disease will affect their behavior in particular to do prevention or looking for treatment. Those who feel the disease affected will sooner feel threatened. Someone will act to prevent the disease when she felt that quite possibly exposed to the illness. A vulnerability where each individual differs depending on the risk by individuals at a particular.

\begin{tabular}{c}
\hline REFERENCES \\
\hline Amiruddin F, Ibnu IF, Rahman MA (2012). \\
Implementasi Strategi AKMS dalam \\
Penanggulangan TB Paru oleh 'Aisyi- \\
yah Muhammadiyah di Kota Maka- \\
sar'. Fakultas Universitas Hasanudin \\
Makasar.
\end{tabular}

Ary D, Arsyad DS, Rismayanti (2014). Pemanfaatan Imunisasi di Kelurahan Pampang Kecamatan Panakkukang Kota Makassar (Pendekatan Health Belief Model). Bagian Epidemiologi Fakultas Kesehatan Masyarakat Universitas Hasanudin Makassar.

Awusi RYE, Saleh YD, Hadiwijoyo D (2009). Faktor-faktor yang Mempengaruhi Penemuan Penderita TB Paru di Kota Palu Provinsi Sulawesi Tengah. Berita Kedokteran Masyarakat. 25 (2): 59-68.

Bandura A (1986). Social Foundation of Thought and Action: A Social Cognitive Theory. New Jersey: Practice-H.

Deci E, Ryan R (2008). Facilitating Optimal Motivation and Psychological Well Being Across Life's Domain. Can Psychol, 14-23.

Depkes RI (2009). Buku Saku Kader Program Penaggulangan TB. Jakarta: Direktorat Jenderal Pengendalian Penyakit dan Penyehatan Lingkungan.
Dwijayanti YR, Herdiana I (2011). Perilaku Seksual Anak Jalanan Ditinjau dengan Teori Health Belief Model (HBM). Fakultas Psikologi Universitas Airlangga.

Glanz K, Rimer BK, Lewis FM (2002). Health Behavior and Health Education. Theory, Research and Practice. San Fransisco: Wiley \& Sons.

Has EMM (2012). Perilaku Ibu dalam Pemenuhan Gizi Anak Usia Prasekolah Berbasis Integrasi Health Promotion Model dan Self Regulation Theory. Surabaya: Universitas Airlangga.

Hayati M (2010). Hubungan Kemampuan Metakognitif dan Efikasi Diri dengan Prestasi Ketrampilan Laboratorium Kimia Analitik Mahasiswa Analis Kesehatan. Tesis Magister Kedokteran Keluarga Pascasarjana UNS.

Kemkes RI (2015). Infodatin TB 2015. (2013). Pedoman Nasional Pelayanan Kedokteran Tata Laksana Tuberkulosis. 1-110.

Khayati, Nur (2012). Beberapa Faktor yang Berhubungan dengan Pelaksanaan Surveilans Epidemiologi Malaria Tingkat Puskesmas di Kabupaten Purworejo. Jurnal Kesehatan Masyarakat.

Kurniawati C, Sulistyowati M (2014). Aplikasi Teori Health Belief Model dalam Pencegahan Keputihan Patologis. Jurnal Promkes. 2(2): 117-127.

Maryun Y (2007). Beberapa Faktor yang Berhubungan dengan Kinerja Petugas Program TB Paru terhadap Cakupan Penemuan Kasus BTA (+) di Kota Tasikmalaya Tahun 2006.1-125.

Rosenstock (1982). Historical Origins of The Health Belief Model. In: Becker, Marshall H. Eds. The Health Belief Model and Personal Health Behavior. Charles B. Slack Inc, Thorofare, New Jersey. 
Steingart KR (2014). Xpert@ MTB/ RIF Assay for Pulmonary Tuberculosis and Rifampicin Resistance in Adults. The Cochrane Database of Systematic Reviews, 1(1):CDoo959.

Subagiyo AAA (2014). Health Belief Model sebagai Pembentuk Perilaku Sehat.

Trisnawati G (2008). Pelatihan Peningkatan Kemampuan Kader dalam Penanganan Tuberkulosis (TBC) di Wilayah Kerja Puskesmas Gemolong
II Sragen. Jurnal Warta. 11(2): 150158.

Wahyudi E (2010). Hubungan Pengetahuan, Sikap dan Motivasi Kader dengan Penemuan Suspek Tuberkulosis Paru di Puskesmas Sanankulon.

WHO (2006). The Stop TB Strategy. World Health Organization. 